\title{
The Activity of Cellulase Enzymes of Ganoderma applanatum and Ganoderma tropicum
}

\author{
Nyi Mekar Saptarini ${ }^{1 *}$, Ginayanti Hadisoebroto ${ }^{2}$ \\ ${ }^{1}$ Department of Pharmaceutical Analysis and Medicinal Chemistry, Faculty of Pharmacy, Universitas Padjadjaran, Jl Raya Bandung Sumedang km 21, \\ Jatinangor, Indonesia. ${ }^{2}$ Department of Pharmacy, Faculty of Mathematics and Natural Sciences, Universitas Al Ghifari, Jl Cisaranten 140, Bandung, \\ Indonesia.
}

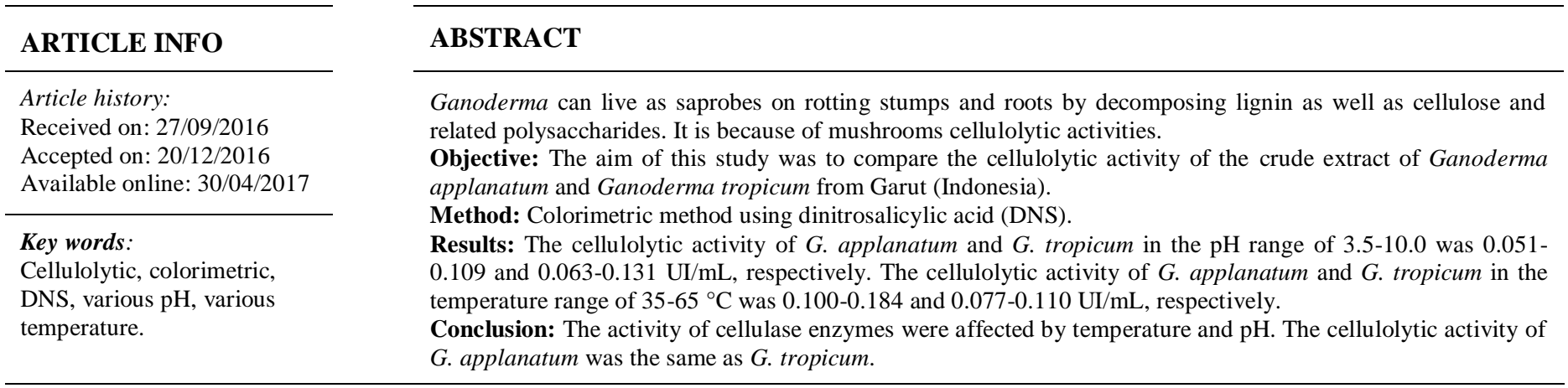

\section{INTRODUCTION}

The genus Ganoderma (Ganodermataceae) found in subtropical and tropical regions, because they can survive under hot and humid conditions. Ganoderma species contain chemical constituents such as polysaccharides, proteins, amino acids, fatty acids, terpenoids, steroids, alkaloids, and phenolic compounds, with potential nutritional and therapeutic values (Mizuno, 1995, Paterson, 2006, Singh et al., 2013). Ganoderma species grow as a facultative parasite that can live as saprobes on rotting stumps and roots (Pilotti et al., 2004) by decomposing lignin as well as cellulose and related polysaccharides (Hepting, 1971). We believe these mushrooms have cellulolytic activity which controlled and processed by cellulase system. Currently, cellulase enzyme was used in various industrial processes, such as biofuels

* Corresponding Author

Nyi Mekar Saptarini, Department of Pharmaceutical Analysis and Medicinal Chemistry, Faculty of Pharmacy, Universitas Padjadjaran, Jl Raya Bandung Sumedang km 21, Jatinangor, Indonesia.

Email: nyi.mekar@unpad.ac.id
(Vaithanomsat et al., 2009), triphase biomethanation (Chakraborty et al., 2000), plants and agriculture waste processing (Mswaka and Magan, 1998, Lu et al., 2004). We see the opportunities of usage of $G$. applanatum and $G$. tropicum in agriculture waste processing. This study aimed to compare the cellulytic activity of the cellulase enzyme of $G$. applanatum and $G$. tropicum which grow on a dead stump of bitter bean (Parkia speciosa) in various $\mathrm{pH}$ and temperature.

\section{MATERIALS AND METHODS}

\section{Materials}

Ganoderma applanatum and Ganoderma tropicum were collected from a dead stump of bitter bean (Parkia speciosa) in the Cipangramatan village, Garut sub-district, Indonesia, in July 2015. Mushrooms were identified by School of Biological Sciences and Technology, Bandung Institute of Technology, Indonesia with No. 1996/I1.CO2.2/PL/2015. All chemical reagents are analytical grade (Merck), including glucose and dinitrosalicylic acid (Sigma Aldrich). 


\section{Preparation of Dinitrosalicylic Acid (DNS) Reagent}

A total of $5 \mathrm{~g}$ of sodium hydroxide, $91 \mathrm{~g}$ of potassium sodium tartrate, $5 \mathrm{~g}$ of sodium sulfite, $1 \%$ phenol, and $5 \mathrm{~g}$ of DNS were dissolved in $500 \mathrm{~mL}$ distilled water. The mixture was homogenized using a magnetic stirrer. The solution was stored in amber bottles and low temperature (Benfeld, 1955).

\section{Determination of Standard Curve}

A total of $1 \mathrm{~mL}$ of the glucose solution $(0.25,0.50,0.75$, 1.00 , and $1.25 \mu \mathrm{g} / \mathrm{mL}$ ) in a different tube was added by $1 \mathrm{~mL}$ of DNS reagent. The color was then developed by boiling the mixture for $5 \mathrm{~min}$. Optical densities were measured at $575 \mathrm{~nm}$ against a blank containing all the reagents minus glucose (Miller, 1959).

\section{Extraction of Crude Enzyme}

Mushrooms were washed and dried to a constant weight. A total of $5 \mathrm{~g}$ of mushrooms and $25 \mathrm{~mL}$ of phosphate buffer $\mathrm{pH}$ 7.0 were mashed for $5 \mathrm{~min}$. The extract was filtered, then centrifuged for $15 \mathrm{~min}$ at $4000 \mathrm{rpm}$ to obtain supernatant which contain the cellulase enzyme.

\section{Determination of the Cellulolytic Activity}

A total of $1 \mathrm{~mL}$ of the supernatant, $0.5 \mathrm{~mL}$ of phosphate buffer, and $1 \mathrm{~mL}$ of $1 \% \mathrm{CMC}$ were mixed and incubated for 30 min at $25{ }^{\circ} \mathrm{C}$. The reaction was terminated by adding $1 \mathrm{~mL}$ of DNS reagent. The color was then developed by boiling the mixture for 5 min. Optical densities were measured at $575 \mathrm{~nm}$ against a blank containing all the reagents minus the crude enzyme (Miller, 1959). The cellulolytic activity was determined at various $\mathrm{pH}(3.5,5.8$, $7.0,8.0$, and 10.0), and various temperature $(25,35,45,55$, and 65 $\left.{ }^{\circ} \mathrm{C}\right)$.

Enzyme activity $(\mathrm{IU} / \mathrm{mL})=\frac{\text { glucose level } \mathrm{x} \text { dilution factor }}{\text { glucose } \mathrm{MW} \times \text { incubation time }}$

\section{Statistical Analysis}

Results are presented as the mean \pm standard error of the mean (SEM). Data comparisons between groups were done by two way ANOVA followed by Tukey-Kramer post hoc test. Values were considered statistically significant at $P<0.05$.

\section{RESULTS AND DISCUSSION}

Both of ganoderma in this study were grown on a dead stump of bitter bean. The size of $G$. applanatum was $27 \pm 2 \mathrm{~cm}$ in length, $20 \pm 3 \mathrm{~cm}$ in width, $5 \pm 1 \mathrm{~cm}$ in height, and brown colored. The size of $G$. tropicum was $25 \pm 3 \mathrm{~cm}$ in length, $15 \pm 2 \mathrm{~cm}$ in width, $5 \pm 2 \mathrm{~cm}$ in height, and white brownish colored because of spores (Fig. 1). Both mushrooms have morphology according the literature. The growth of Ganoderma is influenced by the environmental conditions, specific host species, and the habitat nature (Turner, 1981). Different species of Ganoderma produced different feature and pathogenecity (Wong et al., 2012).
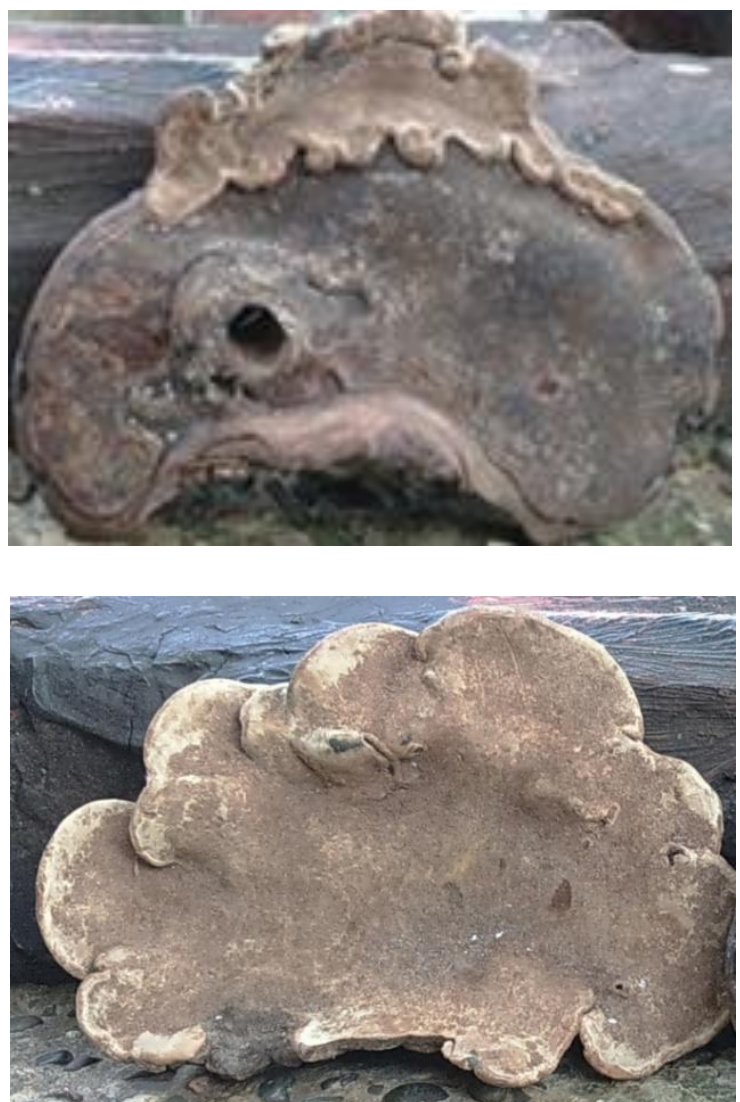

Fig. 1: Ganoderma applanatum (above) and G. tropicum (below)

\section{Determination of Standard Curve}

The reaction between glucose and DNS involves the oxidation of the aldehyde functional group in the glucose and 3,5dinitrosalicylic acid (DNS) is reduced to 3-amino,5-nitrosalicylic acid under alkaline conditions, simultaneously (Miloski et al., $2008)$. The correlation coefficient value was close to $1.00\left(\mathrm{R}^{2}=\right.$ 0.9961, Fig. 2) met the criteria by ICH (ICH, 2005) and showed that the instrument response was proportional to the glucose concentration.

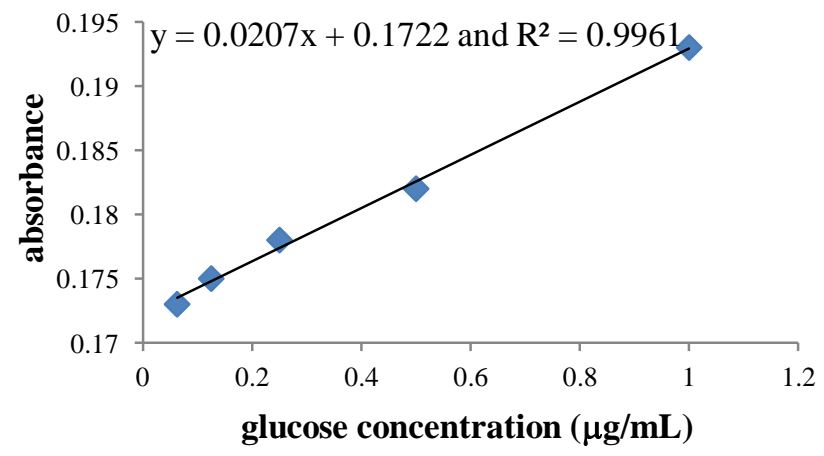

Fig. 2: Glucose calibration curve.

\section{Extraction of Crude Enzyme}

Cellulase enzymes were extracted using phosphate buffer $\mathrm{pH} 7.0$ to maintain the stability and function of cellulase enzymes 
in the crude extract. The extract were cloudy solution, so conducted the centrifugation to separate the supernatant from the residues. The color of clear supernatant was yellowish-white for G. applanatum, and brown for G. tropicum.

\section{Determination of the Cellulolytic Activity}

The cellulase system consists of three classes of soluble extracellular enzymes, i.e 1,4- $\beta$-endoglucanases, $1,4-\beta$ exoglucanases, and $\beta$-glucosidases ( $\beta$-Dglucoside glucohydrolases or cellobiases) (Shewale, 1982). These enzymes hydrolyze cellulose to glucose (Ryu and Mandels, 1980). Substrates for the cellulolytic activity assay was carboxy methyl celulose (CMC) which dispersed in water, the hydrophilic moieties of CMC absorb the water absorbing, then swelling, so the viscosity increased. The efficient enzymatic degradation of insoluble polysaccharides, such as cellulose, requires a tight interaction between the enzymes and substrates. In the cellulose degradation, many cellulases are known to bind to crystalline and/ or amorphous cellulose via cellulose binding domains (CBDs) which are distinct from the catalytic domains (Aderemi et al., 2008).

The cellulase enzyme of $G$. tropicum is more active than G.applanatum at $\mathrm{pH} 3.5-10.0$, but at $\mathrm{pH} 7.0$, both enzymes have equal activity (Fig. 3). We suggested that the cellulase enzyme of G. tropicum is more stable to $\mathrm{pH}$ alteration compared to $G$. applanatum. The unfavorable $\mathrm{pH}$ may result in reduced enzyme activities by reducing accessibility of the substrate (Bakri et al., 2008).

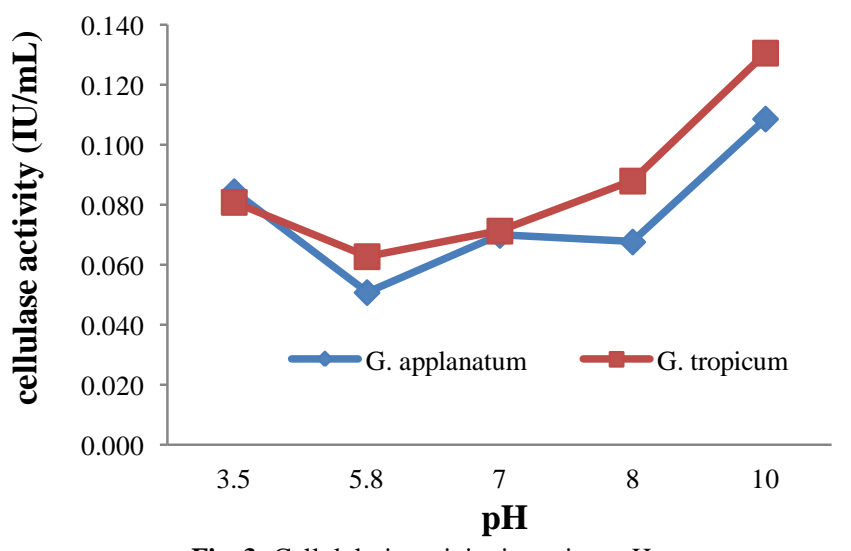

Fig. 3: Cellulolytic activity in various $\mathrm{pH}$.

The cellulase enzyme of $G$. applanatum is more active than G. tropicum at temperature of $25-65{ }^{\circ} \mathrm{C}$, but at $35^{\circ} \mathrm{C}$, both enzyme have equal activity (Fig. 4). We suggested that the cellulase enzymes of $G$. applanatum more stable to temperature alteration compared to G. tropicum. The cellulases catalytic activity is inhibited at higher temperatures. Increasing temperature was supposed to denature and unfold the proteins, thus may cause two different effects, i.e. more ionic groups of the proteins become exposed to the surface and are available to dye fixation dan more tryptophan residues formerly hidden inside the 3D-structure are revealed and thus may lead to an increase in hydrophobic interactions between protein and cellulose. Higher temperatures (above $30{ }^{\circ} \mathrm{C}$ ) alter the cell membrane composition and stimulate protein catabolism, causing cell death (da Silva et al., 2005).

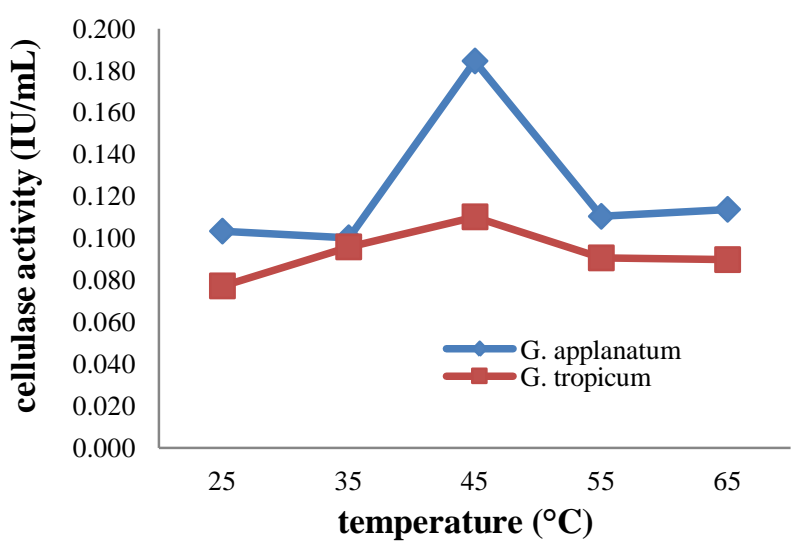

Fig. 4: Cellulolytic activity in various temperature.

\section{Statistical Analysis}

There was statistically significant on temperature $(P=$ $0.0064)$ and $\mathrm{pH}(P=0.0087)$, but there was no statistically significant on Ganoderma species for various temperature $(P=$ $0.1576)$ and various $\mathrm{pH}(P=0.1081)$.

\section{CONCLUSION}

The activity of cellulase enzymes were affected by temperature and $\mathrm{pH}$. The cellulolytic activity of G. applanatum was the same as G. tropicum.

\section{ACKNOWLEDGEMENTS}

We are thankful to Indra Permana and Sugiarto for their technical support.

Financial support and sponsorship: Nil.

Conflict of Interests: There are no conflicts of interest.

\section{REFERENCE}

Aderemi BO, Abu E, Highina BK. The kinetics of glucose production from rice straw by Aspergillus niger. African J Biotech, 2008; 7:1745-52.

Bakri Y, Jawahar M, Arabi MIE. Improvement of xylanase production by Cochliobus sativus in submerged culture. Food Technol Biotech, 2008; 46:116-18.

Benfeld P. Amylases $\alpha$ and $\beta$. Methods Enzymol, 1955; 1:14958.

Chakraborty N, Sarkar GM, Lahiri S. Cellulose degrading capabilities of cellulolytic bacteria isolated from the intestinal fluids of the silver cricket. Enviromentalist, 2000; 20:9-11.

da Silva R, Lago ES, Merheb CW, Macchione MM, Park YK, Gomes E. Production of xylanase and CMCase on solid state fermentation in different residues by Thermoascus aurantiacus miehe. Brazilian J Microbiol, 2005; 36:235-41.

Hepting GH. 1971. Diseases of forest and shade trees of the United States. In: Flood J, Bridge PD, Holderness M, eds. Ganoderma diseases of perennial crops. UK: CABI Publisher. 
ICH. 2005. Validation of analytical procedures: text and methodology Q2(R1). In: Guideline ICH Harmonized Tripartite, ed. International Conference on Harmonisation of Technical Requirements for registration of pharmaceuticals for human use. Geneva.

Lu WJ, Wang HT, Nie YF. Effect of inoculating flower stalks and vegetable waste with ligno-cellulolytic microorganisms on the composting process. J Environmental Science and Health Part B, 2004; 39:871-87.

Miller GL. Use of dinitrosalycylic acid reagent for determination of reducing sugar. Anal Chem, 1959; 31:426.

Miloski K, Wallace K, Fenger A, Bendinkas ESK. Comparison of biochemical and chemical digestion and detection methods for carbohydrates. Am J Undergrad Res, 2008; 7:7-19.

Mizuno T. Bioactive biomolecules of mushrooms: food function and medicinal effect of mushroom fungi. Food Rev Int, 1995; 11: 7-21.

Mskawa AY, Magan N. Wood degradation, and cellulase and ligninase production, by Trametes and other wood-inhabiting basidiomycetes from indigenous forests of Zimbabwe. Microbiol Study, 1998; 102:1399-404.

Paterson RRM. Ganoderna: a therapeutic fungal biofactory. Phytochem, 2006; 67:1985-2001.

Pilotti CA, Sanderson FR, Aitken AB, Armstrong W. Morphological variation and host range of two Ganoderma species from Papua New Guinea. Mycopathologia, 2004; 158:251-65.
Ryu DDY, Mandels M. Cellulases: biosynthesis and applications. Enzyme and Microbial Techn, 1980; 2:91-102.

Shewale JG. Glucosidase: its role in cellulase synthesis and hydrolysis of cellulose. Int J Biochem, 1982; 14:435-43.

Singh SK, Doshi A, Pancholy A, Pathak R. Biodiversity in wood-decay macro-fungi associated with declining arid zone trees of India as revealed by nuclear rDNA analysis. Eur J Plant Pathol, 2013: 1-10.

Turner PD. 1981. Oil plam diseases and disorders. UK: Oxford University Press.

Vaithanomsat P, Chuichulcherm S, Apiwatanapiwat W. Bioethanol production from enzymatically saccharified sunflower stalks using steam explotion as pretreatment. Proceeding of World Academy of Science, Engineering and Technology, 2009; 37:140-3.

Wong CL, Bong JFC, Idris AS. Ganoderma species associated with basal stem root disaese of oil palm, Am J App Sci, 2012; 9:879-85.

\section{How to cite this article:}

Saptarini NM, Hadisoebroto G. The Activity of Cellulase Enzymes of Ganoderma applanatum and Ganoderma tropicum. J App Pharm Sci, 2017; 7 (04): 134-137. 